\title{
PIJAT KOMBINASI ENDORFIN OKSITOSIN MEMPENGARUHI PRODUKSI ASI PADA IBU POST OPERASI SECTIO CAESAREA
}

\author{
Nursari Abdul Syukur ${ }^{1)}$ Endah Wahyutri ${ }^{2}$ Erma Futri ${ }^{3)}$ \\ ${ }^{1,2)}$ Jurusan Kebidanan, Poltekkes Kemenkes Kaltim, J1. Wolter Monginsidi No.38, \\ Samarinda, 75123 \\ ${ }^{3)}$ Bidan, Rumah Sakit Samarinda Medika Citra, Jl. Kadrie Oening No.86 RT. 35, \\ 75124 \\ E-mail : nursarias@gmail.com
}

\begin{abstract}
Breast milk spending is a very complex interaction between mechanics, nerves, and hormons. The decrease and production of breast milk production in the first days after delivery can be caused by a lack of stimulation of prolactin and oxytocin hormons. Caesarea section does not allow the mother to breastfeed her infant more flexibly, with adaptation to the pain. This study to know the difference of endorphin, oxytocin and combination effect on breast milk production in Postoperative section of caesarea section. This study using quasi experimental design type post test only non equivalent control group design. The population in this study were all postoperative mothers caesarea section, 10 samples for each treatment. Group 1 : endorphin massage, group 2 (control) : the oxytocin massage, and group 3 : the combine massage. Combination massage is the best method to produce the highest amount of ASI because the largest Sig p value is $(1,000)$ where the level is significant $<0.05$. So H0 this study was rejected means that there is a significant difference between the production of breast milk from the combination massage compared with the two massage done separately. It is expected during childbirth the midwife can develop and implement independent non-pharmacological to help increase milk production.
\end{abstract}

Keywords: Massage of endorphins, oxytocin, combination, milk production

\begin{abstract}
Abstrak
Pengeluaran ASI merupakan suatu interaksi yang sangat kompleks antara mekanik, syaraf, dan hormon. Penurunan dan produksi pengeluaran ASI pada hari pertama setelah melahirkan dapat disebabkan oleh kurangnya rangsangan hormon prolaktin dan oksitosin. Proses operasi section caesarea tidak memungkan ibu untuk dapat menyusui bayinya lebih fleksibel, maka ibu harus dapat dukungan tenaga kesehatan secara menyeluruh tentang proses laktasi. Tujuan penelitian mengetahui perbedaan pengaruh pijat endorfin, oksitosin dan kombinasi terhadap produksi ASI pada Ibu Post operasi section caesarea. Penelitian ini menggunakan desain quasi eksperimen jenis post test only non equivalent control group design. Populasi dalam penelitian ini semua ibu post operasi section caesarea, sampelnya 10 orang untuk setiap kelompok. Kelompok 1 : pijat endorfin, kelompok 2 (Kontrol) : pijat oksitosin, dan kelompok 3 : pijat kombinasi. Pijatan kombinasi adalah metode terbaik untuk menghasilkan jumlah ASI yang terbanyak karena nilai Sig paling besar yaitu $(1,000)$ dimana tingkat signifikan $<0,05$. Maka H0 penelitian ini diterima artinya terdapat perbedaan signifikan antara produksi ASI dari pijatan kombinasi dibandingkan dengan ke dua pijatan dilakukan secara terpisah. Bidan dapat mengembangkan tindakan mandiri non farmakologis untuk membantu meningkatkan produksi ASI
\end{abstract}

Kata Kunci : Pijat endorfin, oksitosin, kombinasi, produksi ASI 


\section{PENDAHULUAN}

Menyusui sejak dini mempunyai dampak yang positif baik bagi ibu maupun bayinya. Bagi bayi, menyusui mempunyai peran penting untuk menunjang pertumbuhan, kesehatan, dan kelangsungan hidup bayi, karena ASI kaya dengan zat gizi dan antibodi. Sedangkan bagi ibu, menyusui dapat mengurangi morbiditas dan mortalitas karena proses menyusui akan merangsang kontraksi uterus sehingga mengurangi perdarahan pasca melahirkan (Manuaba, 2007).

Peraturan pemerintah tentang pemberian ASI eksklusif (PP no. 33 tahun 2012, PP No. 97 tahun 2018) Dalam PP tersebut diatur tugas dan tanggung jawab pemerintah dan pemerintah daerah dalam pengembangan program ASI, diantaranya menetapkan kebijakan nasional dan daerah, melaksanakan advokasi dan sosialisasi serta melakukan pengawasan terkait program pemberian ASI eksklusif. Menindak lanjuti PP tersebut, telah diterbitkan Permenkes no.15 tahun 2013 tanggal 18 Februari 2013 tentang tata cara penyediaan fasilitas khusus menyusui dan / atau memerah ASI dan permenkes nomor 39 tahun 2013 tanggal 17 Mei tahun 2013 tentang susu formula bayi dan produk lainnya (Kemenkes RI, 2013).

Pengeluaran ASI merupakan suatu interaksi yang sangat kompleks antara mekanik, syaraf, dan bermacam-macam hormon. Dalam hal produksi ASI, penurunan dan produksi pengeluaran ASI pada hari-hari pertama setelah melahirkan dapat disebabkan oleh kurangnya rangsangan hormon prolaktin dan oksitosin. Kedua hormon tersebut sangat berperan dalam proses laktasi. Penyebab tidak keluarnya ASI pada hari-hari pertama setelah melahirkan menjadi salah satu penyebab tidak terwujudnya pemberian ASI eksklusif. Pada masalah pengeluaran ASI dini bisa terjadi pada ibu yang mengalami proses persalinan melalui tindakan Sectio Caesarea (SC). Ibu yang mengalami operasi SC akan mengalami kesulitan dalam melakukan inisiasi menyusu dini, kondisi luka operasi pada perut Ibu, kelemahan akibat pengaruh anastesi yang diberikan sebelumnya, oleh karena itu pasien dengan operasi SC sebagian baru berhasil menyusui setelah lewat beberapa jam pasca melahirkan (Saleha, 2009).

Tindakan anastesi epidural pada pasien section caesarea menyebabkan 
terhambatnya pengeluaran hormon oksitosin. Dengan adanya pengaruh terapi anastesi, tidak memungkinkan ibu untuk dapat senantiasa menyusui banyinya dari waktu ke waktu pada masa awal persalinan. Efek samping anastesi seperti rasa mual, pusing, menggigil mungkin masih saja dapat dirasakan ibu pada masa di ruang pemulihan (Leveno, 2009).

Penelitian yang dilakukan oleh Faridah H dkk tahun 2013, pijat oksitosin dapat mempengaruhi faktor psikologis sehingga meningkatkan relaksasi dan tingkat kenyamanan pada ibu, sehingga mempengaruhi produksi ASI. Efek pijat terhadap produksi ASI lebih banyak dan ASI keluar lancar lebih awal yaitu pada hari ke 2. Ada perbedaan signifikan antara produksi ASI ibu nifas setelah mendapatkan pijat oksitodin dan tidak.

Hasil studi pendahuluan yang dilakukan di RSU Samarinda Medika Citra, pada akhir tahun 2015 angka kelahiran dengan section caesarea mencapai 1071 kelahiran, pada tahun 2016 mencapai 1575 angka kelahiran dengan section caesarea dan hingga bulan November tahun 2017 angka kelahiran dengan section caesarea mencapai 1536 kelahiran. Berdasarkan protap yang berlaku di RSU SMC, rawat gabung dapat dilakukan setelah bayi melewati masa observasi selama 6 jam pertama kelahiran. Pengamatan yang dilakukan pada $12 \mathrm{ibu}$ post section caesarea di bulan November, didapatkan semua ibu tetap mencoba untuk menyusui bayinya pada 6 jam setelah kelahiran bayi, namun tidak semua dapat berhasil. Sebagian besar ibu masih mengalami kesulitan dalam melakukan mobilisasi karena efek anastesi dan rasa nyeri yang mulai dirasakan oleh ibu. Sebagian besar ibu tidak yakin bahwa ASInya keluar. 7 orang ibu baru benarbenar merasa nyaman untuk mencoba belajar menyusi setelah dapat duduk walaupun masih terpasang infus dan dauer catether. Pengeluaran kolostrum pada awal persalinan yang tampak saat petugas kesehatan memeriksa payudara ibu ada pada sekitar $5 \mathrm{ibu}$, dengan semua ibu memerlukan intervensi tambahan berupa perawatan payudara.

Penelitian yang dilakukan pada ibu post operasi section caesarea karena adaptasi terhadap rasa nyeri, maka ibu harus dapat dukungan tenaga kesehatan secara menyeluruh tentang proses laktasi. Mengajarkan ibu berbagai teknik untuk membuat ibu lebih rileks dan memberikan kelancaran dalam produksi ASI pada masa awal persalinan. Untuk memperlancar proses laktasi dan upaya dalam mendukung proses pemberian ASI 
eksklusif, maka dapat dilakukan dengan teknik pijat endhophin, pijat oksitosin, dan kombinasi keduanya.

Berdasarkan uraian diatas penulis tertarik untuk melakukan penelitian studi kasus tentang "Pengaruh Pijat Endorfin, Oksitosin, dan Kombinasi Endorfine Oksitosin terhadap Produksi ASI pada Ibu Post Operasi Section Caesarea di RSU Samarinda Medika Citra tahun 2018”

\section{METODE PENELITIAN}

Jenis penelitian yang digunakan pada penelitian ini adalah observasi analitik dengan menggunakan metode quasi experiment. Desain ini menggunakan post test only non equivalent control group design. Kesimpulan hasil penelitian didapat dengan cara membandingkan data post test antara kelompok perlakuan dengan kelompok kontrol (Kelana 2017, hal 9394).

Populasi dari penelitian ini adalah ibu primipara yang melahirkan secara sectio pada hari ke 2 post operasi. Populasi terjangkau adalah yang lahir secara sectio cesarea dengan keadaan umum yang tanpa komplikasi pada ibunya.Sampel dari penelitian ini adalah ibu post operasi section caesarea yang memenuhi kriteria inklusi.Sampel penelitian dipilih secara consecutive sampling dengan kriteria sebagai berikut, Ibu yang melahirkan bayi berusia reproduktif antara (20-35 tahun), usia kehamilan 37-40 minggu, bersedia mengikuti penelitian dan bersedia dihubungi kembali sebagai responden saat pengambilan data akhir, kondisi bayi dalam keadaan klinis sehat, indikasi Operasi karena penyulit yang tidak mempengaruhi keadaan umum setelah melahirkan, dan ibu tidak mengalami komplikasi selama operasi, berdomisili di wilayah Samarinda, bayi tidak diberikan susu formula atau tambahan lain selama dilakukan penelitian, dilakukan pemijatan dan mengajarkan kepada keluarga pada hari ke dua, selanjutnya hari ke 3, dan hari ke 4, dan bentuk Putting ke dua payudara ibu normal.

Teknik pengumpulan data menggunakan data primer yang dikumpulkan menggunakan lembar observasi. Analisis yang digunakan adalah analisis perbedaan non parametric lebih dari 2 mean dengan uji Anova untuk mengetahui perbedaan antar variansi.

\section{HASIL DAN PEMBAHASAN}

Tabel karakterisitik responden

\begin{tabular}{|c|c|c|c|}
\hline No. & $\begin{array}{c}\text { Karaktersitik } \\
\text { Responden }\end{array}$ & $\begin{array}{c}\text { Frekuensi } \\
\text { (n) }\end{array}$ & $\begin{array}{c}\text { Persentasi } \\
(\%)\end{array}$ \\
\hline \multirow[t]{6}{*}{1.} & Paritas & & \\
\hline & - anak ke 1 & 13 & 43,33 \\
\hline & - $\quad$ anak ke 2 & 13 & 43,33 \\
\hline & - $\quad$ anak ke 3 & 3 & 10,00 \\
\hline & - $\quad$ anak ke 4 & 1 & 3,33 \\
\hline & Jumlah & 30 & $100^{5}$ \\
\hline \multirow[t]{4}{*}{2.} & Umur & & \\
\hline & $-26-30$ & 15 & 50,00 \\
\hline & $-20-25$ & 9 & 30,00 \\
\hline & $31-35$ & 6 & 2000 \\
\hline
\end{tabular}


Dari 30 responden penelitian berdasarkan karakteristik masing masing dapat terlihat bahwa mayoritas responden pada karakteristik paritas adalah pada anak ke-1, anak ke-2, mayoritas pada karakteristik usia adalah 26-30 tahun, mayoritas pada pendidikan adalah SMA dan mayoritas pekerjaan karakteristik adalah IRT. Adapun hasil identifikasi produksi ASI untuk masingmasing perlakuan hari 23 , dan 4 adalah sebagai berikut
Tabel 1. Produksi ASI pada Setiap Perlakuan Hari ke 2,3 dan 4 pada Ibu Post Sectio Caesarea (hasil dalam satuan cc)

\begin{tabular}{llccc}
\hline $\begin{array}{c}\text { Metode } \\
\text { Perlaku } \\
\text { an }\end{array}$ & $\begin{array}{l}\text { Standar } \\
\text { Desriftif }\end{array}$ & & Hari & \\
\hline Endorphi & & $\mathbf{2}$ & $\mathbf{3}$ & $\mathbf{4}$ \\
$\mathrm{n}$ & Rata - & 1.98 & 3.67 & 6.81 \\
& rata & & & \\
& Maksimal & 2.30 & 4.50 & 7.80 \\
& Minimal & 1.10 & 2.90 & 4.80 \\
& St. & 0.46 & 0.46 & 0.89 \\
Oksitosin & Deviasi & & & \\
& Rata - & 2.22 & 3.61 & 5.89 \\
& rata & & & \\
& Maksimal & 4.80 & 4.70 & 7.30 \\
& Minimal & 1.00 & 2.10 & 4.10 \\
& St. & 1.06 & 0.78 & 0.83 \\
Kombina & Deviasi & & & \\
si & Rata - & 3.67 & 5.20 & 7.38 \\
& rata & & & \\
& Maksimal & 6.70 & 6.70 & 8.90 \\
& Minimal & 1.70 & 2.70 & 4.80 \\
& St. & 1.59 & 1.20 & 1.35 \\
& Deviasi & & & \\
\hline
\end{tabular}

Data pada Tabel diatas menjelaskan distribusi frekuensi produksi ASI pada hari ke 2, 3, dan 4 pada tiap perlakuan. Pada hari ke 2 rata-sata untuk pijat endorfin produksi ASI adalah 1,98 cc, pijat oksitosin 2,22 cc, dan pijat kombinasi rata-rata 3,67 cc. Produksi ASI rata-rata pada hari ke 2 pijat endorfin 3,67cc, pijat oksitosin 3,61, dan pijat kombinasi $5,20 \mathrm{cc}$. Produksi ASI rata-rata pada hari ke empat pijat endorfin 6,81, pijat oksitosin 5,89, dan pijat kombinasi $7,38 \mathrm{cc}$.

Analisa dalam penelitian ini untuk mengetahui pengaruh pijat endorfin, pijat oksitosin dan pijat kombinasi terhadap 
produksi ASI dengan sampel untuk masing-masing perlakuan adalah 30 orang dengan. Sebelum dilakukan uji Anova maka dilakukan uji normalitas data dan homogenitas terlebih dahulu.

Tabel Analisa Statistik Pengaruh Perbedaan Pijat Endorfin, Oksitosin, dan Kombinasi Endorfin Oksitosin Terhadap Produksi ASI

\begin{tabular}{lcc}
\hline Analisa statistik & P value & $\begin{array}{c}\boldsymbol{P} \\
\text { value }\end{array}$ \\
\hline Uji normalitas & 0,938 & \\
Uji Homogen & 0,765 & \\
Uji anova & 0,003 & \\
Post Hock & & \\
- $\quad \begin{array}{l}\text { Pasangan } \\
\text { endorfin- } \\
\text { oksitosin }\end{array}$ & & \\
- $\quad$ & 0,995 \\
$\quad \begin{array}{l}\text { Pasangan } \\
\text { endorfin- } \\
\text { kombinasi } \\
\text { Pasangan } \\
\text { oksitosin- } \\
\text { kombinasi }\end{array}$ & & \\
\hline
\end{tabular}

Berdasarkan uji statistik dengan perangkat lunak computer uji normalitas data diketahui bahwa Sig $\alpha$ adalah 0,938> 0,05 maka data produksi ASI untuk semua sampel pada semua perlakuan berdistribusi normal. Setelah data terdistribusi normal dilakukan uji homogenitas varian dengan Lavene test hasilnya Sig $\alpha$ adalah 0,765 >0,05 maka berarti variansi produksi ASI hari ke 2, 3, dan 4 homogen (identik). Dari hasil asumsi diatas memenuhi persyaratan uji Anova dengan hasil Sig $\alpha 0,003<0,05$ maka metode pijatan endorfin, oksitosin dan kombinasi terdapat perbedaan ratarata jumlah produksi ASI.

Uji varian sebagai uji lanjutkan yang dilakukan guna menentukan metode pijatan mana yang lebih berpengaruh dalam menghasilkan jumlah ASI yang lebih berpengaruh dengan menggunakan Post Hock Test, dengan analisis Uji Turkey yang pertama dilakukan adalah membandingkan Metode Endorfin dengan metode Oksitosin dimana kesimpulan rata-rata ASI yang dihasilkan pada kedua metode pijatan sama - sama memiliki jumlah ASI yang dihasilkan. Uji varian selanjutnya membandingkan metode pijatan Endorfin dengan metode pijatan Kombinasi. Pada perbandingan kedua metode ini jumlah ASI yang dihasilkan tidak sama dengan rata-rata jumlah ASI yang menggunakan Metode Pemijatan Kombinasi. Begitu pula dengan perbandingan Metode pijatan Oksitosin dibandingkan dengan metode pijatan kombinasi yang menghasilkan jumlah rata - rata yang tidak sama dengan hasil produksi ASI yang dihasilkan dengan metode Pijatan Kombinasi. Kesemua uji varian ini berdasarkan hasil keputusan uji statistic F dengan taraf kepercayaan $95 \%$.

Uji terakhir yang dilakukan adalah analisis Uji LSD, uji ini sama dengan Uji Turkey HSD yang sudah dilakukan pada 
uji sebelumnya. Dengan menggunakan Homogeneous Subsets untuk melihat dari ketiga metode yang dilakukan, manakah metode yang paling perpengaruh pada produksi ASI Ibu Post Sectio Caesarea. Kesimpulan pada penelitian ini adalah hasil Pijatan kombinasi adalah metode yang terbaik untuk menghasilkan jumlah ASI yang terbanyak karena nilai Sig paling besar yaitu $(1,000)$

\section{PEMBAHASAN}

\section{Karakteristik Ibu Post Operasi Sectio} Caesarea meliputi Paritas, Umur, pendidikan dan Pekerjaan.

Dari 30 responden yang ditemukan menentukan pengambilan keputusan untuk memberikan ASI.

Karakteristik pekerjaan terlihat bahwa sebagian besar responden IRT sebanyak 19 orang atau $63.33 \%$. Penelitian tahun 2013 oleh Lestari, status pekerjaan ibu merupakan faktor yang memproteksi dalam artian ibu yang tidak bekerja lebih banyak waktu dan lebih fleksibel untuk memberikan ASI dari pada ibu yang bekerja.

\section{Identifikasi Produksi ASI pada Ibu} Post Sectio Caesarea pada hari ke $2,3,4$
Berdasarkan hasil penelitian produksi ASI, terlihat mayoritas paritas adalah anak ke 1 yaitu 43,3\% dan anak ke 2 yaitu 43,3\%. Pengalaman menyusui sebelumnya juga dapat mempengaruhi keberhasilan dalam pemberian ASI ekslusif, pada ibu yang pertama kali hamil sehingga belum berpengalaman dalam pemberian ASI dan memungkinkan ibu tidak mengetahui hal-hal yang terkait dengan ASI. Responden dengan produksi ASI terbanyak pada penelitian ini adalah paritas anak ke 4. Hal ini seiring dengan penelitian Astuti (2017) variabel paritas dengan multiparitas pada kelompok multiparitas dengan produksi ASI lancar uji statistic nilai $\mathrm{p}=0,013$ sehinga dapat dikatakan bahwa paritas dengan multiparitas berpengaruh terhadap produksi ASI

Sesuai kriteria inklusi Ibu yang melahirkan bayi berusia reproduktif antara (20-35 tahun), umur responden terbanyak berusia 26-30 tahun sebanyak 15 orang atau $50 \%$ dari total sampel. Semua responden tidak ada yang memiliki umur kurang dari 20 tahun atau lebih dari 35 tahun. Berdasarkan umur jika $<16$ tahun atau > 35 tahun akan membuat wanita rentan terhadap sejumlah komplikasi Hal ini memerlukan pengawasan antenatal tambahan. (Varney, 
2008). Terdapat kesesuaian antara teori dan responden yang ditemukan, bahwa semua responden tidak termasuk kategori usia yang dapat dikategorikan dalam kehamilan resiko tinggi.

Karakteristik pendidikan terlihat mayoritas pendidikan SMA sebanyak 14 orang yaitu 46,6\%. Menurut Tirtaraharja (2005) dalam bukunya yang berjudul Pengantar Pendidikan, pendidikan diperlukan untuk mendapaktan informasi yang menunjang kesehatan sehingga dapat meningkatkan kualitas hidup. Sejalan dengan penelitian yang dilakukan oleh Widiyanto (2012) menunjukan semakin rendah pendidikan semakin rendah kemampuan dasar seseorang dalam berfikir untuk.

Hari ke 2, 3, dan 4 terjadi peningkatan rata-rata produksi ASI. Hal ini sesuai dengan siklus laktasi menurut Anik (2015) bahwa proses laktogenesis memang bertahap dari laktogenesis stadium 1 (dari kehamilan-2 hari post partum), laktogenesis stadium 2 (hari ke 2-hari kedelapan) kemudian Galaktopoeisis (hari ke 9-awal involusi), dan involusi (rata-rata 40 hari setelah involusi). Hasil penelitian ini jika dibandingkan dengan produksi ASI berdasarkan Tabel Asupan rata-rata dalam penelitian yang di lakukan Wahyutri
(2013) dimana rata-rata pada ibu post section 0-24 jam $4 \mathrm{ml} / \mathrm{kg}, \quad 24-48$ jam $13 \mathrm{ml} / \mathrm{kg} / \mathrm{bb}$, dan13,5-14ml.

Aspek status gizi maternal sejak masa kehamilan meliputi kenaikan BB sampai dengan status gizi laktasi perlu menjadi pertimbangan dalam pengaruhnya terhadap masa laktasi. Penelitian Irawati tahun 2003 di Indonesia menunjukkan adanya pengaruh status gizi ibu pada masa laktasi terhadap keberhasilan menyusui, ibu yang kurang gizi berisiko tidak berhasil menyusui 2,26 - 2,56 kali lebih besar dibandingkan ibu dengan gizi baik. Ibu hamil yang mengalami kenaikan BB lebih rendah dari BB yang direkomendasikan mempunyai cadangan lemak rendah. Situasi ini akan memengaruhi kemampuan ibu memproduksi ASI.

Fikawati tahun 2012 melihat hubungan antara kenaikan BB ibu dan Persepsi Ketidakcukupan Air Susu Ibu (PKA), menunjukkan hubungan yang signifikan antara kenaikan BB ibu dan PKA. Studi secara konsisten dilakukan oleh Fikawati menunjukkan bahwa status gizi ibu hamil yang diukur melalui kesesuaian kenaikan BB ibu selama hamil dan PKA memiliki hubungan yang erat dan bermakna. 
Hasil ketiga studi telah membuktikan adanya keterkaitan erat antara aspek fisio-biologis dengan aspek psikoemosional pada ibu hamil dan menyusui.

\section{Analisa Pengaruh Pijat Endorfin,} Oksitosin dan Kombinasi Endorfin Oksitosin

Berdasarkan hasil penelitian ini metode yang dapat menghasilkan produksi ASI yang lebih banyak adalah metode kombinasi pijatan endorfin dan oksitosin, bila dibandingkan pijatan dilakukan secara terpisah. Hal ini sejalan dengan hasil penelitian Wahyuningsih (2016) kelancaran ASI responden mengalami perubahan sebanyak $80 \%$ peningkatan produksi ASI setelah dilakukan pijat endorfin. Hasil penelitian Astuti dkk (2015) juga menyatakan bahwa tindakan pijat punggung (Pijat oksitosin) dan memerah ASI berpengaruh baik terhadap produksi ASI yang lancar pada ibu postpartum dengan seksio sesarea. Menurut Nurizah (2011) metode pijat kombinasi dari pijat endorphine dan oksitosin merupakan stimulasi yang memegang peranan penting pada hipofisis. Peranan hipofisis adalah mengeluarkan endorphine (endegeneus opiate) yang efeknya menyerupai heroin dan morfin. Zat ini berkaitan dengan penghilang nyeri alamiah (analgesic). Peranan selanjutnya mengeluarkan prolaktin yang akan memicu dan mempertahankan sekresi air susu dari kelenjar mammae.

Menurut Roesli tahun 2005, ibu yang sedang menyusui dapat mengalami gangguan produksi ASI jika dalam keadaan cemas dan stress. Pengeluaran ASI akan berlangsung baik pada ibu yang merasa rileks dan nyaman. Metode pijat endorfin yang di kombinasikan dengan pijat oksitosin akan menghasilkan refleks let down yang baik. Let down refleks adalah refkleks yang bertanggung jawab menyalurkan susu dari payudara ke bayi, dan di kendalikan oleh kadar oksitosin. Perawatan pemijatan yang dilakukan secara berulang dapat meningkatkan produksi hormon oksitosin

Menurut Kusumaningrum (2016) ibu menyusui harus dalam kondisi rileks. Secara tidak langsung kondisi psikologis sangat berpengaruh terhadap proses laktasi. Penelitian yang dilakukan $>80 \%$ kegagalan dalam menyusui pada masa awal adalah karena kondisi psikologis. Pikiran ibu yang banyak tekanan, rasa khawatir yang berlebihan akan merangsang pada saat yang bersamaan 
ratusan sensor pada otak akan memerintahkan hormon oksitosin bekerja lambat sehingga dapat memicu terjadinya bendungan ASI. Sehingga stimulasi kombinasi endorfin dan oksitosin akan memberikan ibu perasaan lebih rileks yang cukup efektif untuk mengeluarkan ASI dan memcegah terjadinya bendungan pada payudara. Hal ini disebabkan karena pijatan berupa sentuhan ringan merangsang tubuh untuk melepaskan senyawa endorphin yang dapat menormalkan denyut jantung, tekanan darah, mengendalikan rasa nyeri dan memicu perasaan nyaman.

Responden dalam penelitian ini yang tidak homogen, yaitu bervariasi ada yang paritas anak pertama atau primipara, ada pula yang multipara. Semakin tinggi paritas akan mempengaruhi proses selama laktasi pada masa nifas. Wanita yang melahirkan anak pertama akan mempengaruhi proses persalinan dan nifas. Pada ibu primipara, proses adaptasi nifas dan menyusui berlangsung lebih lama, karena belum ada pengalaman pada kehamilan yang lalu termasuk dalam hal menyusui.

Pada Ibu usia muda yang sedang menyusui tetapi dengan gizi yang baik, ASI dapat mencukupi kebutuhan bayi. Menurut Arini, H (2012), faktor usia yang terlalu muda atau terlalu tua dapat menyebabkan pengaruh pada pengalaman proses kehamilan dan persalinan. Latar belakang kejiwaan wanita yang bersangkutan seperti tingkat pendidikan, status perkawinan, kehamilan yang tidak diinginkan, riwayat kejiwaan sebelumnya, sosial ekonomi sertadukungan sosial dapat mempengaruhi proses selama nifas.

Faktor kejiwaan ibu juga dapat menghambat refleks let down atau refleks pengeluaran ASI diantaranya stress, seperti : keadaan bingungan tidak stabil, takut dan cemas. Keadaan kejiwaan ibu yang cemas dan pikiran yang stress, bingung, kacau dapat menghambat proses hormon oksitosin reflek let down atau reflek pengeluaran ASI. Produksi ASI yang terus berlangsung, tetapi pengeluaran terhambat sehingga menyebabkan bendungan ASI (Manuaba, 2007).

Kesimpulan pada penelitian ini adalah hasil pijatan kombinasi adalah metode yang terbaik untuk menghasilkan jumlah ASI yang terbanyak karena nilai $p$ value $0,003<0,05$ sehingga ada pengaruh perbedaan rata-rata produksi $\mathrm{ASI}$, dan uji lanjutan sig paling besar berdasarkan Uji LSD sebagai kelanjutan dari Uji Tukkey untuk melihat metode yang terbaik diantara ke tiganya nilai Sig $\alpha(1,000)$ dan 
Jumlah Rata-rata ASI yang dihasilkan dengan metode ini sebesar 5,40 cc. Hasil analisa terakhir yang dilakukan dengan perangkat lunak menemukan adanya perbedaan yang signifikan produksi ASI pada pijatan kombinasi endorphin dan oksitosin, dibandingkan jika ke 2 pijatan dilakukan terpisah. Namun, masing masing tetap menghasilkan produksi ASI. Artinya pijatan kombinasi memberikan pengaruh atau dengan kata lain terbukti efektif untuk meningkatkan produksi ASI pada ibu post Sectio caesarea.

Kesimpulan diatas menunjukan adanya pengaruh pijat endorfin, oksitosin dan pijat kombinasi endorfin oksitosin terhadap produksi ASI pada ibu post section caesarea, maka hipotesis nul (Ho) dalam penelitian ini ditolak, maka hipotesis alternative (Ha) diterima.

\section{SIMPULAN}

1. Karakteristik ibu menyusui di Wilayah Kerja RS. Samarinda Medika Citra adalah mayoritas Paritas anak ke-1 dan 2 sebanyak 43,33\%, mayoritas usia 26 - 30 sebanyak 50,00 \%, mayoritas Pendidikan SMA sebanyak 46,67\% dan mayoritas Pekerjaan Ibu Rumah Tangga (IRT) sebanyak 63,33\%.
2. Rata-rata produksi ASI pada hari ke 2 adalah 2,62 cc, pada hari ke 3 adalah $4,16 \mathrm{cc}$, pada hari ke 3 adalah 6,43cc

3. Analisa pengaruh pijat endorfin terhadap produksi ASI pada hari ke 2 rata-rata keluar adalah $2,22 \mathrm{cc}$, hari ke 3 3,61cc, hari ke 4 5,89cc. Hasil Sig $\alpha$ $0,000<0,005$ maka terdapat perbedaan rata-rata jumlah ASI pada hari ke 2, 3, dan 4

4. Analisa pengaruh pijat oksitosin terhadap produksi ASI pada hari ke 2 rata-rata keluar adalah $1,98 \mathrm{cc}$, hari ke 3 3,67cc, hari ke 4 6,21cc. Hasil Sig $\alpha$ $0,000<0,005$ maka terdapat perbedaan rata-rata jumlah ASI pada hari ke 2, 3, dan 4

5. Analisa pengaruh pijat Kombinasi terhadap produksi ASI pada hari ke 2 rata-rata keluar adalah 3,67 cc, hari ke 35,20 cc, hari ke 4 7,38 cc. Hasil Sig $\alpha$ $0,000<0,005$ maka terdapat perbedaan rata-rata jumlah ASI pada hari ke 2, 3, dan 4

6. Analisa pengaruh pijat endorfin, oksitosin, dan kombinasi terhadap produksi ASI Hasil Sig $\alpha 0,003<0,05$ maka terdapat perbedaan rata-rata jumlah ASI pada hari ke 2, 3, dan 4 maka Ho ditolak, dan Ha diterima. 
Ucapan terimakasih kepada seluruh responden yang telah membantu penelitian ini, dan terimakasih buat RS SMC Samarinda yang telah memberikan izin tempat penelitian

\section{DAFTAR PUSTAKA}

Arini, H. (2012). Mengapa seorang ibu harus menyusui. Yogyakarta: FlashBooks.

Astuti, Rusmil RP, Permadi K, Wiryawan C. M, Efendi J, Jusuf S.Al, Dewi M D, H. (2015). Pengaruh Pijat Punggung dan Memerah ASI terhadap Produksi ASI pada Ibu Postpartum dengan Seksio Sesarea. Indonesia Journal of Education and Midwifery Care, 2(1), 1-8. Retrieved from http://ijemc.unpad.ac.id/ijemc/artic le/viewFile/7/4.

Azizah, I.N; Widyawati, Nurul M; Anggraini, N. N. (2013). Pengaruh Endorphin Massage Terhadap Intensitas Nyeri Kala I Persalinan Normal Ibu Primipara Di Bps S Dan B Demak Tahun 2011. Jurnal Kebidanan, 2(1), 90-96. https://doi.org/http://dx.doi.org/10. 1016/j.talanta.2008.05.019

Dharma, K. K. (2011). Metodologi penelitian keperawatan: Panduan melaksanakan dan menerapkan hasil penelitian.

Dinas Kesehatan Kota Samarinda. (2015). Profil Kesehatan Tahun 2016.

Fikawati, S., \& Syafiq, A. (2011). Status Gizi Ibu dan Persepsi Ketidakcukupan Air Susu Ibu Maternal Nutritional Status and Breast Milk Insufficiency Perception. Jurnal Kesehatan Masyarakat Nasional, 6(6), 249254. Retrieved from http://journal.fkm.ui.ac.id/index.ph p/kesmas/article/viewFile/77/78

Kementerian Kesehatan RI. (2013). Tentang Tata Cara Penyediaan Fasilitas Khusus Menyusui dan / atau memerah ASI .

Kusumaningrum, A.T. and Aris, A. (2016). Efektifitas Kombinasi Stimulasi Oksitosin Dan Endorfin Massage Terhadap Kejadian Bendungan ASI Pada Ibu Post Partum Primipara. Jurnal stikes mulha. Vol. 08, No. 03

Leveno, K. J., McIntire, D. D., Bloom, S. L., Sibley, M. R., \& Anderson, R. J. (2009). Decreased preterm births in an inner-city public hospital. Obstetrics \& Gynecology, 113(3), 578-584. 
Manuaba, I., \& Bagus, G. (2007). Ilmu Penyakit Kebidanan. Kandungan dan Pelayanan KB untuk pendidikan Bidan, Jakarta : EGC.

Mardiyaningsih E ,Setyowati, S. L. (2011). Efektifitas Kombinasi Teknik Marmet dan Pijat Oksitosin Terhadap Produksi ASI pada Ibu Post Seksio Di Rumah Sakit Wilayah Jawa Tengah. Jurnal Keperawatan Soedirman, 6(1), 56-61. Retrieved from http://www.jks.fikes.unsoed.ac.id/i ndex.php/jks/article/viewFile/321/ 164

Notoatmodjo, S. (2010). Metodologi Penelitian Kesehatan, Rineka Cipta. Jakarta. Indonesia.

Pollard, M. (2015). ASI Asuhan Berbasis Bukti. EGC.Roesli, U.\& Yohwi E. 2009. Manajemen Laktasi. Jakarta ; IDAI

Saleha, S. (2009). Asuhan kebidanan pada masa nifas. Jakarta: Salemba Medika.

Wahyuningsih E; Rohmawati W. (2016). Efektivitas pijat endorpin dan pijat. Jurnal Stikes Muhammadiyah Klaten, 9 (17), 47-60. Retrieved from http://jurnal.stikesmukla.ac.id/inde
x.php/involusi/article/viewFile/38 $9 / 370$

Wahyutri, Endah. 2013. Model Pengaruh Dukungan Sebaya Dan Suami Pada Ibu Hamil Terhadap Kelancaran Produksi ASI Dan Keputusan Menyusui (Pendekatan Theory of Planned Behavior/TPB). Surabaya.Hasil desertasi. Universitas Airlangga 